http://nv.nltu.edu.ua

\title{
ВПЛИВ ПОЛІЕЛЕМЕНТНОГО СКЛАДУ БАТАРЕЙОК НА СТАН ДОВКІЛЛЯ ТА ВИЗНАЧЕННЯ НАДІЙНОСТІ ЕКОСИСТЕМ
}

\begin{abstract}
Здійснено класифікацію та стандартизацію хімічних джерел струму. Наведено результати паретто-аналізу показників небезпеки складу відпрацьованих алкалінових батарей. Реалізовано метод енергодисперсійного рентгенофлуоресцентного аналізу речовин. Відкориговано показники ступеня небезпеки з урахуванням частки (мас. \%) кожного елемента досліджуваних батарейок та оцінено сумарні показники ступеня небезпеки поліелементного складу батарейок. Запропоновано новий підхід до оцінювання впливу не просто батарейки, як такої, а ії полікомпонентного складу на стан довкілля, через визначення надійності екосистем, що дає змогу отримати кількісні показники стійкості та втрати природних екосистем, що можуть бути використані як індикатори стану довкілля, а відтак оцінки екологічної складової, важливої для визначення реального впливу поліелементного складу батарейок. В аспекті забезпечення переходу суспільства на засади сталого розвитку важливо оцінити ризики втрати, знищення екосистем, що тісно пов'язано з їхньою стійкістю. Стійкість екосистем розглянуто як здатність зберігати свою структуру і характер функціонування у просторі та часі за впливу змін умов зовнішнього середовища. На основі таких показників, які можна отримати за допомогою програмного забезпечення SimaPro, можливий розрахунок тих порогових величин, поза якими відбуваються негативні явища, прогнозування та моделювання ситуацій, картування джерел ризиків, моніторинг змін, а це дасть змогу виявити причини цих змін, або встановити чинники, що сповільнюють чи стримують наближення екосистем до критичного стану, тобто розробити превентивні заходи запобігання катастрофам. Використаний есо-індикатор $99 €$ одним із методів, який дає нам змогу прийняти одну оцінку для всього продукту - так званий екологічний індекс. Це сума всіх окремих еко-точок або часткових індексів для всіх процесів життєвого циклу. Обчислювальна процедура здійснюється шляхом підсумовування результатів зважування фаз життєвого циклу.
\end{abstract}

Ключові слова: надійність; екосистема; батарейки; поліелементний склад; SimaPro; вплив.

Вступ. У разі потрапляння відпрацьованих батарейок у потік твердих побутових відходів і їх подальшого захоронення внаслідок механічних пошкоджень і корозії порушується герметичність корпусу і відбувається виділення їх вмісту. Високий вміст у батарейках свинцю, кадмію та інших важких металів і сполук, які володіють небезпечними властивостями, надалі призводить до забруднення навколишнього середовища та втрати екологічної надійності екосистемою. При цьому надійність екосистеми визначається як здатність екосистеми та ії окремих частин протистояти коливанням зовнішніх чинників і зберігати свою структуру і функціональні особливості.

Класифікація і стандартизація хімічних джерел струму (ХДС). Хімічні джерела струму поділяють на первинні і вторинні батареї. Первинні ХДС призначені для одноразового використання і містять певну кіль- кість активних речовин, після їх використання первинні батареї втрачають працездатність. Вторинні ХДС, або акумулятори, призначені для багаторазового використання. У разі розрядження акумулятор працює як первинний ХДС, при цьому відбувається перетворення хімічної енергії вихідних активних речовин в електричну. Акумулятори допускають безліч циклів заряду - розряду (Taganova \& Bubnov, 2002; Korovin \& Skundin, 2003).

Для уніфікації ХДС розроблено міжнародні стандарти, які маркують джерела живлення за фізичними параметрами і хімічним складом. Так, наприклад, Американський національний інститут стандартів (American National Standards Institute - ANSI) класифікує ХДС за фізичними параметрами без вказівки хімічного складу. У старій системі ANSI позначення розпочиналося 3 літери (або літер), що означає (ї) систему і типорозмір, потім позначали цифри, що означають розміри. У но-

Інформація про авторів:

Петрушка Ігор Михайлович, д-р техн. наук, професор, завідувач кафедри екологічної безпеки та природоохоронної діяльності. Email: Petim@ukr.net

Руда Марія Віталіївна, канд. техн. наук, асистент, кафедра екологічної безпеки та природоохоронної діяльності. Email: marichkarmv@gmail.com; https://orcid.org/0000-0003-0590-4589

Гивлюд Анна Миколаївна, канд. техн. наук, асистент, кафедра екологічної безпеки та природоохоронної діяльності. Еmail: anna.hyvlyud@gmail.com.

Коваль Надія Миронівна, пров. спеціаліст, кафедра екологічної безпеки та природоохоронної діяльності. Email: beshnadia@gmail.com

Цитування за Дсту: Петрушка І. М., Руда М. В., Гивлюд А. М., Коваль Н. М. Вплив поліелементного складу батарейок на стан довкілля та визначення надійності екосистем. Науковий вісник НлТУ України. 2019, т. 29, № 3. С. 64-70.

Citation APA: Petrushka, I. M., Ruda, M. V., Hyvlyud, A. M., \& Kovalj, N. M. (2019). Impact of multi-element composition of battery on the state of the environment and determination of ecosystem reliability. Scientific Bulletin of UNFU, 29(3), 64-70. https://doi.org/10.15421/40290314 
вих стандартах позначення розпочинається з цифр, що означають, зазвичай, типорозмір (Hsing Po Kang, 2012ж Khan \& Kurny, 2012).

Міжнародна електротехнічна комісія (МЕК) класифікує хімічні джерела струму за позначенням форм, типорозмірів і електрохімічних систем. Стандартні позначення первинних ХДС визначаються на підставі цифр (число послідовно з'єднаних елементів, типорозмір) i букв (електрохімічна система) (Sayilgan et al., 2009). Наприклад, на батареї вказано таке маркування: LR20. Перша літера позначає електрохімічну систему (сукупність активних речовин і електроліту, на основі яких створено хімічний джерело струму): первинні ХДC: L для лужних батарей, $\mathrm{S}$ - для срібно-цинкових, $\mathrm{C}$ - для літієвих і перша буква відсутня - для сольових батарей; вторинні ХДС: К - для нікель-кадмієвих акумуляторів, $\mathrm{H}$ - для нікель-металогідридного, SR - для срібно-цинкового акумулятора.

Друга літера визначає форму: $\mathrm{R}$ - циліндрична, $\mathrm{F}$ плоска, $\mathrm{S}$ - призматична. Цифрове значення вказує радіус (розмір) джерела живлення в міліметрах. У позначеннях ХДС можуть зазначатися варіанти виконання: $\mathrm{S}$ - зі стандартною ємністю, $\mathrm{C}$ - 3 підвищеною ємністю (на 20-25\% вище, ніж у S) і Р з більшою потужністю (порівняно з потужністю $\mathrm{C}$ i S за ємності, що приблизно дорівнює ємності варіанта 3) (Zapolskyi, Saliuk \& Sytnyk, 2001).

У табл. 1 наведено позначення деяких циліндричних ХДС за різними стандартами.

Табл. 1. Позначення та типорозмір циліндричних ХДС

\begin{tabular}{|c|c|c|c|c|}
\hline Позначення & $\begin{array}{c}\text { ANSI } \\
\text { колишній }\end{array}$ & $\begin{array}{c}\text { ANSI } \\
\text { новий }\end{array}$ & $\begin{array}{c}\text { Висота, } \\
\text { мм }\end{array}$ & $\begin{array}{c}\text { Діаметр, } \\
\text { мм }\end{array}$ \\
\hline R1 & N & 910 & 30,2 & 12,0 \\
\hline R03 & AAA & 24 & 44,5 & 10,5 \\
\hline R6 & AA & 15 & 50,5 & 14,5 \\
\hline R14 & C & 14 & 50,0 & 26,2 \\
\hline R20 & D & 13 & 61,5 & 34,1 \\
\hline
\end{tabular}

Мета дослідження - встановити екологічний вплив поліелементного складу батарейок i визначити надійність екосистем.

Методика визначення поліелементного складу батарейок. Дослідження проводили на моделі "ЕХPERT 3L" - прилад для проведення прецизійних вимірювань в умовах стаціонарних і мобільних лабораторій, розроблений ТОВ "НВП Інститут аналітичних методів контролю" (IHAM) - українське підприємство, яке спеціалізується на розробленні методик і випуску засобів аналітичного контролю для здійснення експертиз і поточних аналізів елементного складу речовини. Енергодисперсійний рентгенофлуоресцентний аналізатор "ЕXPERT 3L" (далі - Аналізатор) призначений для вимірювання масової частки елементів з атомними номерами від 12 (магній) до 92 (уран) в однорідних монолітних зразках металевих сплавів (зливки, деталі, фольги, дріт). Для області призначення Аналізатор є універсальним прямопоказуючим приладом, який оперативно без зміни калібрувань і переналаштування визначає масові частки (\%) хімічних елементів у зразках невідомого складу і довільної форми (Polygalov, Ilinykh \& Bazyleva, 2015; Hopper, 2009; Grime, 1979).

За наявності даних про стехіометрію хімічних сполук, які можуть входити в склад об'єкта експертизи, Аналізатор здатний оцінити вміст цих сполук у зразку без попереднього градуювання (Ruda, Hyvlyud \& Lentyakov, 2018; Molchanov, 1976; Svirizhev \& Logofet,
1978). Прецизійний кількісний аналіз вмісту хімічних елементів в об'єктах додаткової сфери застосування Аналізатора проводиться за окремими методиками i потребує попереднього його градуювання із застосуванням стандартних зразків або робочих еталонів складу відповідних об'єктів аналізу (зовнішніх стандартів).

В Аналізаторі реалізований метод енергодисперсійного рентгенофлуоресцентного аналізу (РФА) речовин. Перевага цього методу перед іншими - повне збереження об'єкта аналізу від пошкоджень: неруйнівний контроль для об'єктів аналізу (Glensdorf \& Prigozhin, 1973; Ghrodzynsjkyj, 1995; Obshta et al., 2018). Метод дає змогу визначати склад шару речовини аналізованого об'єкта завтовшки від 10 мкм до 1 мм залежно від щільності і складу шару. Принцип дії РФА полягає у збудженні атомів об'єкта контролю зовнішнім джерелом іонізуючого випромінювання та подальшої реєстрації характеристичного рентгенівського випромінювання (ХРВ) атомів. Енергія ХРВ однозначно пов'язана зі структурою рівнів атома конкретного хімічного елемента (Gorshkov, 1995; Didukh, 2011; Zaika, 2007). Для якісного аналізу достатньо $з$ допомогою рентгенівського спектрометра визначити енергії ліній ХРВ від об'єкта i за їх значенням ідентифікувати наявні елементи. Кількісний аналіз базується на затвердженні пропорційності між інтенсивністю ХРВ елемента і його вмістом в об'єкті контролю. В Аналізаторі в ролі зовнішнього джерела застосовано малопотужний пристрій на рентгенівській трубці, а для зменшення часу отримання повного спектру ХРВ - всехвильовий рентгенівський спектрометр на напівпровідниковому PIN-детекторі 3 термоохолоджувачем.

Методика встановлення екологічного впливу поліелементного складу батарейок на стан довкілля. Програмне забезпечення SimaPro є професійним інструментом для збирання, аналізу та моніторингу екологічних характеристик продуктів. За його допомогою можна легко моделювати й аналізувати складні життєві цикли систематизованим та зрозумілим способом.

Для аналізу впливу на довкілля поліелементного складу батарейок використовували методику "Eco-індикатор 99", для цього були згруповані необхідні дані, а саме: основні матеріали, що потрібні для виготовлення батарейок, комплектуючі кожної складової сировини та матеріалу, які розглядають як входи; процеси, такі як транспортування, безпосередній процес виготовлення, що супроводжують життєвий цикл продукту (виходи). Для зручності роботи складові частини процесу були згруповані у дві групи: необхідні природні ресурси; технічні та технологічні засоби. Поступово до програми заносились дані про окремі частини процесу із зазначенням складових матеріалів, компонентів і процесів, що їх супроводжували.

Програмне забезпечення (ПЗ) SimaPro дає змогу аналізувати продукти 3 урахуванням сценаріїв поводження 3 відходами, який можна моделювати самостійно, залежно від обраного продукту. Після закінчення побудови дерева ми провели аналіз оцінки впливів на довкілля. Процес аналізу складався 3 таких п'яти елементів: характеризація; оцінювання шкоди; нормалізація; зважування; визначення екологічного індексу.

Наступним кроком стало продовження аналізу життєвого циклу на основі характеризації. Це групи входів і виходів, які розподіляються між одинадцятьма 
категоріями впливу відповідно до методології Eco-індикатора 99. Характеризація показує відносну силу небажаних впливів, кожен 3 відповідним матеріалом життєвого циклу полягають у визначенні питомої ваги: канцерогенів, респіраторних речовин, змін клімату, радіації, впливу на озоновий шар, еко-токсичність, викопних видів палива, змін у землекористуванні, мінералів, підкислення / евтрофікації.

Табл. 2. Поліелементний склад досліджуваних батарейок

\begin{tabular}{|c|c|c|c|c|c|c|}
\hline \multirow{2}{*}{$\begin{array}{l}\text { Хімічний } \\
\text { елемент }\end{array}$} & \multicolumn{4}{|c|}{ Склад, \% за масою } & \multicolumn{2}{|c|}{ Концентрація хімічної речовини } \\
\hline & Сольові батарейки & Похибка & Алкалінові батарейки & Похибка & Сольові батарейки & Алкалінові батарейки \\
\hline \multicolumn{7}{|c|}{ Позитивний полюс } \\
\hline $\mathrm{K}$ & - & - & 3,357 & 0,017 & - & $3 \times 10^{-4}$ \\
\hline $\mathrm{Mn}$ & 0,206 & 0,014 & 0,159 & 0,002 & $2 \times 10^{-5}$ & $2 \times 10^{-5}$ \\
\hline $\mathrm{Fe}$ & 92,812 & 0,328 & 61,522 & 0,836 & $93 \times 10^{-3}$ & $62 \times 10^{-3}$ \\
\hline $\mathrm{Ni}$ & - & - & 34,962 & 0,041 & - & $35 \times 10^{-3}$ \\
\hline $\mathrm{Cl}$ & 1,856 & 0,336 & - & - & $2 \times 10^{-4}$ & - \\
\hline $\mathrm{Ca}$ & 2,294 & 0,080 & - & - & $2 \times 10^{-4}$ & - \\
\hline $\mathrm{Cr}$ & 0,050 & 0,008 & - & - & $5 \times 10^{-6}$ & - \\
\hline $\mathrm{Mn}$ & 0,206 & 0,014 & - & - & $2 \times 10^{-5}$ & - \\
\hline $\mathrm{Zn}$ & 1,370 & 0,017 & - & - & $1 \times 10^{-4}$ & - \\
\hline Sn & 1,413 & 0,018 & - & - & $1 \times 10^{-4}$ & - \\
\hline \multicolumn{7}{|c|}{ Ізоляція } \\
\hline $\mathrm{K}$ & - & - & 11,877 & 0,466 & $12 \times 10^{-3}$ & - \\
\hline $\mathrm{Mn}$ & - & - & 0,319 & 0,018 & $3 \times 10^{-5}$ & - \\
\hline $\mathrm{Fe}$ & - & - & 0,077 & 0,011 & $8 \times 10^{-6}$ & - \\
\hline $\mathrm{Zn}$ & - & - & 87,728 & 0,464 & $88 \times 10^{-3}$ & - \\
\hline \multicolumn{7}{|c|}{ Корпус } \\
\hline $\mathrm{Fe}$ & 97,467 & 0,103 & 0,266 & 0,023 & $97 \times 10^{-3}$ & $3 \times 10^{-5}$ \\
\hline $\mathrm{Cu}$ & - & - & 70,421 & 0,136 & - & $70 \times 10^{-3}$ \\
\hline $\mathrm{Zn}$ & - & - & 29,320 & 0,135 & - & $29 \times 10^{-3}$ \\
\hline $\mathrm{Ca}$ & 1,296 & 0,101 & - & - & $1 \times 10^{-4}$ & - \\
\hline $\mathrm{Cr}$ & 0,066 & 0,016 & - & - & $7 \times 10^{-6}$ & - \\
\hline $\mathrm{Mn}$ & 0,357 & 0,018 & - & - & $4 \times 10^{-5}$ & - \\
\hline Sn & 0,814 & 0,017 & - & - & $8 \times 10^{-5}$ & - \\
\hline \multicolumn{7}{|c|}{ Анод } \\
\hline $\mathrm{Mn}$ & - & - & 0,062 & 0,016 & - & $6 \times 10^{-6}$ \\
\hline $\mathrm{Cu}$ & - & - & 31,635 & 0,98 & - & $32 \times 10^{-3}$ \\
\hline $\mathrm{Zn}$ & - & - & 68,393 & 0,099 & - & $68 \times 10^{-3}$ \\
\hline \multicolumn{7}{|c|}{ Катод } \\
\hline $\mathrm{K}$ & - & - & 0,747 & 0,073 & - & $7 \times 10^{-5}$ \\
\hline $\mathrm{Ti}$ & - & - & 0,647 & 0,022 & - & $6 \times 10^{-5}$ \\
\hline $\mathrm{Mn}$ & 45,889 & 0,234 & 0,222 & 0,010 & $46 \times 10^{-3}$ & $2 \times 10^{-5}$ \\
\hline $\mathrm{Fe}$ & 0,915 & 0,119 & 63,455 & 0,790 & $9 \times 10^{-5}$ & $63 \times 10^{-3}$ \\
\hline $\mathrm{Ni}$ & - & - & 34,859 & 0,680 & - & $35 \times 10^{-3}$ \\
\hline $\mathrm{Zn}$ & 53,196 & 0,235 & 0,070 & 0,007 & $53 \times 10^{-3}$ & $7 \times 10^{-6}$ \\
\hline \multicolumn{7}{|c|}{ Аноїдний провідник } \\
\hline $\mathrm{Cl}$ & 21,345 & 3,084 & 7,368 & 0,184 & $21 \times 10^{-3}$ & $7 \times 10^{-4}$ \\
\hline $\bar{K}$ & 10,383 & 1,250 & 0,675 & 0,096 & $10 \times 10^{-3}$ & $7 \times 10^{-5}$ \\
\hline $\mathrm{Ca}$ & 5,135 & 0,686 & 0,200 & 0,037 & $5 \times 10^{-4}$ & $2 \times 10^{-5}$ \\
\hline $\mathrm{Ti}$ & 3,350 & 0,289 & 0,884 & 0,025 & $3 \times 10^{-4}$ & $9 \times 10^{-5}$ \\
\hline $\mathrm{Mn}$ & 7,436 & 0,362 & 0,084 & 0,006 & $7 \times 10^{-4}$ & $8 \times 10^{-6}$ \\
\hline $\mathrm{Fe}$ & 26,620 & 1,136 & 22,79 & 0,123 & $27 \times 10^{-3}$ & $23 \times 10^{-3}$ \\
\hline $\mathrm{Ni}$ & - & - & 7,854 & 0,046 & - & $8 \times 10^{-4}$ \\
\hline $\mathrm{Zn}$ & 23,820 & 1,011 & 60,092 & 0,002 & $24 \times 10^{-3}$ & $60 \times 10^{-3}$ \\
\hline $\mathrm{Rb}$ & 0,273 & 0,056 & 0,002 & 0,001 & $3 \times 10^{-5}$ & $2 \times 10^{-7}$ \\
\hline $\mathrm{Zr}$ & 0,408 & 0,059 & 0,009 & 0,001 & $4 \times 10^{-5}$ & $9 \times 10^{-7}$ \\
\hline $\mathrm{Sn}$ & 0,459 & 0,063 & 0,420 & 0,002 & $5 \times 10^{-5}$ & $4 \times 10^{-5}$ \\
\hline $\mathrm{Pb}$ & 0,770 & 0,097 & 0,943 & 0,004 & $8 \times 10^{-5}$ & $9 \times 10^{-5}$ \\
\hline \multicolumn{7}{|c|}{ Негативний полюс } \\
\hline $\mathrm{K}$ & - & - & 3,357 & 0,152 & - & $3 \times 10^{-4}$ \\
\hline $\mathrm{Mn}$ & - & - & 0,159 & 0,013 & - & $2 \times 10^{-5}$ \\
\hline $\mathrm{Fe}$ & 97,729 & 0,168 & 61,522 & 0,137 & $98 \times 10^{-3}$ & $62 \times 10^{-3}$ \\
\hline $\mathrm{Ni}$ & - & - & 34,962 & 0,83 & - & $35 \times 10^{-3}$ \\
\hline $\mathrm{Zn}$ & - & - & 2,041 & 0,23 & - & $2 \times 10^{-4}$ \\
\hline $\mathrm{Ca}$ & 1,271 & 0,166 & - & - & $1 \times 10^{-5}$ & - \\
\hline $\mathrm{Cr}$ & 0,081 & 0,017 & - & - & $8 \times 10^{-6}$ & - \\
\hline $\mathrm{Sn}$ & 0,919 & 0,030 & - & - & $3 \times 10^{-6}$ & - \\
\hline Пластик & 1,6000 & & 1,000 & - & - & - \\
\hline Папір, картон & 7,6000 & - & 6,000 & - & - & - \\
\hline Інші елементи & 0,600 & - & 0,135 & - & - & - \\
\hline
\end{tabular}

Результати дослідження та їх обговорення. Для якісного аналізу достатньо $з$ допомогою рентгенівського спектрометра визначити енергії ліній XPI від об'єкта i за їх значенням ідентифікувати наявні елементи. Кількісний аналіз базується на затвердженні пропорційності між інтенсивністю XPI елемента і його вмістом в об'єкті контролю. Середні значення хімічного складу досліджуваних батарейок наведено в табл. 2. 
Відкоригувавши показники ступеня небезпеки з урахуванням частки (мас. \%) кожного елемента досліджуваних батарейок можна оцінити сумарні показники ступеня небезпеки поліелементного складу батарейок (рис. 1).

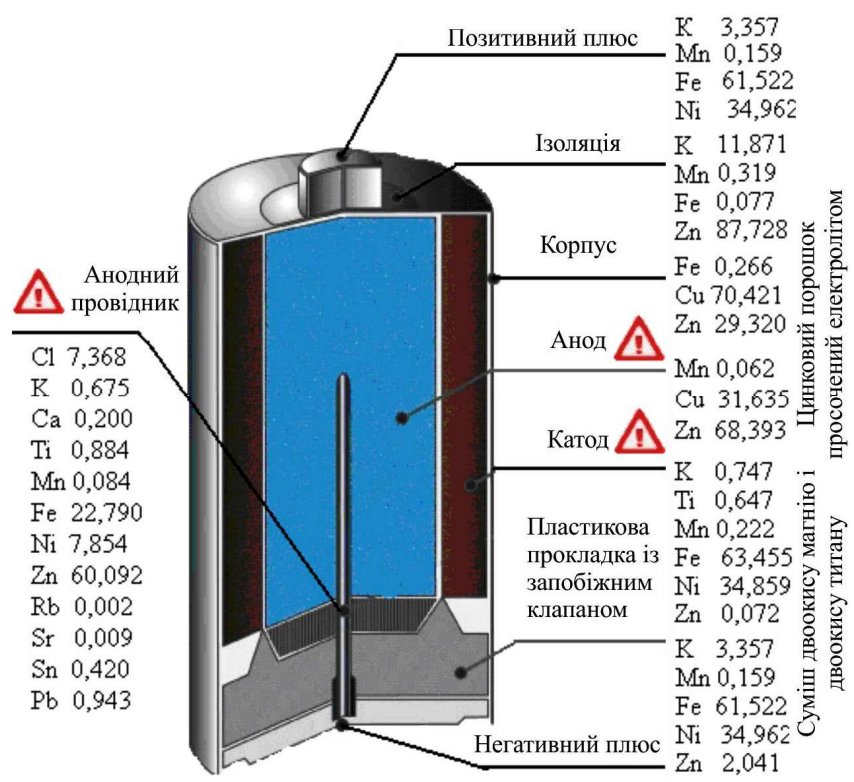

Рис. 1. Поліелементний склад алкалінової батарейки

При цьому, прийнято припущення, що розподіл компонентів батарейок за типами використовуваних систем у проаналізованій пробі відображає їх розподіл у складі твердих комунальних відходів. Для визначення поліелементного складу батарейок, що впливають на навколишнє середовище, виконано аналіз Паретто (рис. 2). Можна зробити висновок, що найбільший вплив на стан навколишнього середовища завдає саме внутрішнє наповнення батарейок. Виходячи 3 цього факту, проведемо аналіз життєвого циклу батарейки.

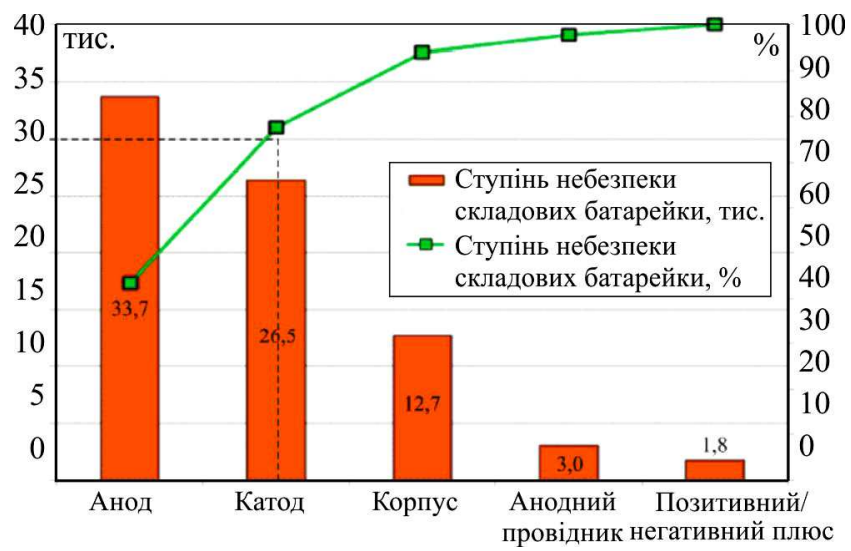

Рис. 2. Результати Паретто-аналізу показників небезпеки складу відпрацьованих алкалінових батарейок

Як обчислювальні процедури, які використовуються для агрегування даних у впливі поліелементного складу батарейок, застосовують екологічні моделі для порівняння різних внесків у ті ж екологічні проблеми. Це завдання може бути досягнуто за допомогою еквівалентності чинників, передбачених моделями (рис. 3).

3 цього графіка бачимо характерні результати специфікації впливу поліелементного складу батарейок на компоненти довкілля, а також сценарії утворення та розповсюдження відходів. Це свідчить про те, що у деяких категоріях впливів домінує транспортування, тоді як наприкінці життєвого циклу домінують інші чинники, всі впливи відображені на 100 \%-й шкалі.

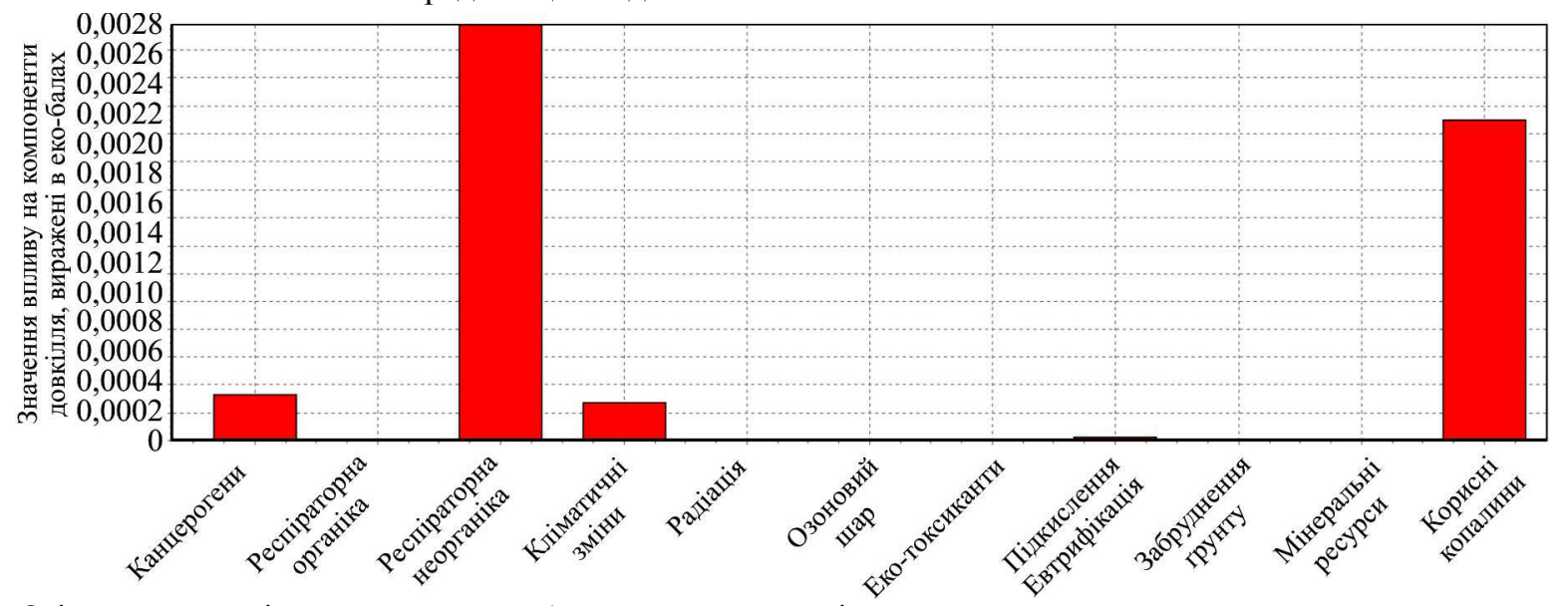

Рис. 3. Оцінка впливу поліелементного складу батарейок на стан довкілля

Як видно з наведеного вище графіка, найбільше негативних впливів на довкілля виникатиме від відходів, тобто від потрапляння полютантів до грунту, тому i маємо відповідний вплив і на еко-токсичність та зміни клімату. Це зумовлено тим, що, потрапляння полютантів через грунтовий шар до рослин, а потім до атмосфери супроводжується таким явищем, як накопичення шкідливих речовин, які внаслідок потрапляють у підземні та поверхневі води, а також спричиняють значне забруднення атмосферного повітря, роблячи відповідний негативний внесок у зміни клімату.

$E c o$-індикатор $99 €$ одним із методів, який дає нам змогу прийняти одну оцінку для всього продукту - так званий екологічний індекс. Це сума всіх окремих еко-то- чок або часткових індексів для всіх процесів життєвого циклу. Обчислювальна процедура здійснюється способом підсумовування результатів зважування фаз життєвого циклу.

Визначення надійності екосистем. Стосовно забезпечення переходу суспільства на засади сталого розвитку важливим є оцінення ризиків втрати, знищення екосистем, що тісно пов'язано 3 їхньою стійкістю. Стійкість екосистем розглядають як здатність зберігати свою структуру і характер функціонування в просторі та часі за впливу змін умов зовнішнього середовища (Korovin \& Skundin, 2003). Теоретичні основи стійкості обгрунтовано у класичних працях Пуан каре, Ляпунова, Лагранже, Свіріжева та Логофета, які грунтуються на 
оцінках засвоєння і трансформації енергії та інформації, тобто законах термодинаміки функціонування екосистем, синергетики, показниках ентропії, що застосовують до відкритих систем (Hsing Po Kang, 2012; Didukh, $2011,17,23]$. Ці автори та їхні послідовники довели, що природний розвиток екосистем хоч і спрямований до рівноважного стану, але у такому стані вони існувати не можуть, а потребують додаткової енергії, що забезпечується завдяки дисипативним процесам. У математичному відношенні зміни поведінки екосистем описуються нелінійними рівняннями. Ці процеси відбуваються як флуктуаційні зміни, що зумовлюють турбулентність і можуть призвести до катастрофи, тобто руйнування екосистеми.

Для нашого дослідження, основним методом визначення надійності екосистем стало створення моделей для оцінювання синергізму дії на екосистему поліелементного складу батарейок. Головні параметри для моделі отримані під час експериментальних досліджень та опрацювання їх за допомогою програмного забезпечення SimaPro. Аналізуючи можливий вплив різних чинників на параметр стійкості - йдеться про визначення міри кількісної оцінки синергізму або антагонізму дії різних чинників на екосистему.

Коефіцієнт синергізму $P$ визначають за такою залежністю:

$$
P=\frac{S_{C d+o n p}}{S_{C d} S_{\text {onp }}} S_{0}
$$

де: $S_{0}$ - відношення чинників впливу на екосистему для контрольного варіанта (кожен із них визначається як відношення швидкостей поглинання полютантів до швидкості його відтоку); $S_{C d+o n p}-$ те саме відношення при комбінованому впливі поліелементного складу батарейок; $S_{C d}$ та $S_{\text {onp }}-$ відношення чинників для незалежних впливів кожного з них.

Підставивши дані, отримані за допомогою SimaPro, отримуємо значення $P=0,752$. Якщо $P=1$, то зрозуміло, що ніякого синергізму в дії різних чинників на параметри немає. Якщо $P<1$, то це може свідчити про істотний внесок синергізму, тобто підсилення дії чинників порівняно $з$ дією окремо кожного з них. Якщо ж $P>1$, то маємо справу 3 антагонізмом, тобто 3 явищем, коли перший чинник зменшує негативну дію наступного, або навпаки. Розроблено схему та введено параметр для оцінювання ступеня взаємодії різних чинників через зазначений вище коефіцієнт - $P$. Коли тривалість спостереження велика, то можна розрахувати та оцінити чинник стійкості. Також варто зазначити, що співвідношення швидкостей поглинання та відтоку полютантів елемента мінерального живлення - пропорційне біомасі біоти та коефіцієнту нагромадження в екосистемі.

Отже, маємо екосистему, яка перебуває під впливом забруднювачів - $Y(x)$ і $Z(x)$, що змінюється 3 часом $x$; $a_{12}$ - швидкість поглинання забруднювачів (пропорційно швидкості поглинання поживних речовин, наприклад калію); $a_{21}-$ швидкість відтоку забруднювачів, наприклад через ентропію. Розв'язком двох диференціальних рівнянь для цієї моделі $є$ :

$$
\begin{gathered}
Y(x)=\frac{Y_{0}}{a_{12}+a_{21}\left(a_{21}+a_{12} \exp \left[-\left(a_{12}+a_{21}\right) x\right]\right)} ; \\
Z(x)=\frac{Y_{0} a_{21}}{a_{12}+a_{21}\left(\exp \left[-\left(a_{12}+a_{21}\right) x\right]\right)} .
\end{gathered}
$$

Виходячи 3 наведеного вище, коли тривалість спостереження тривалий, то можна оцінити чинник надійності так:

$$
F_{b} \approx \frac{a_{12}}{a_{21}+a_{12}} ; \quad F_{w} \approx \frac{a_{21}}{a_{12}+a_{21}},
$$

де: $F_{b}-$ чинник надійності для грунту; $F_{w}-$ чинник надійності для води.

Порівнюючи наведені вище рівняння, отримуємо:

$$
\frac{a_{12}}{a_{21}}=\frac{F_{b}}{F_{w}}=\frac{1-F_{w}}{F_{w}}
$$

Відношення швидкостей поглинання і відтоку забруднювачів і елементів мінерального живлення пропорційне біомасі біоти і коефіцієнту нагромадження в системі "грунт - біота". Це означає, що чим вища біомаса біоти і коефіцієнт нагромадження полютантів біотою, тим вище співвідношення швидкостей поглинання і відтоку полютантів, а отже, і надходження поживних речовин із води до біомаси біоти. Тут добре видно зв'язок параметра надійності за вмістом забруднювачів та швидкостей поглинання і відтоку полютантів.

Побудуємо модель синергізму дії поліелементного складу батарейок на грунт. Як було показано вище, параметри-чинники надійності визначають за такою формулою:

$$
F_{b} \cong \frac{a_{12}}{a_{12}+a_{21}}, F_{w} \cong \frac{a_{21}}{a_{12}+a_{21}}, \frac{F_{b}}{F_{w}}=\frac{a_{21}}{a_{12}} .
$$

Вплив будь-якого полютанта на ці параметри, а отже, і на стан та екологічну безпеку біоти, можна задати так. Очевидно, що надходження полютантів до біоти має змінювати швидкість їх обміну. Тоді за дії забруднювачів вирази для швидкостей можна записати так:

$$
a_{12}=a_{12} c, a_{21}=a_{21} d,
$$

де $c$ i $d$ - коефіцієнти впливу полютантів на параметри надійності за вмістом полютанта.

Параметр $S$ - площа забруднення за дії забруднювача $S_{R}$, який матиме такий вигляд:

$$
S_{R}=\frac{S_{C}}{d}, \text { або } \frac{S_{R}}{S}=\frac{c}{d} .
$$

Відношення величин $S_{R} / S$ може слугувати ступенем впливу забруднювача на параметри стійкості. Чим більше це відношення відрізняється від одиниці, тим більшим є ступінь впливу забруднювача на біоту. При цьому, якщо це відношення дорівнює одиниці, то впливу немає, якщо менше одиниці, то йдеться про пригнічення стану біоти. За значень, більших за одиницю, йдеться про поліпшення стану біоти. При цьому швидкість поглинання забруднювача збільшується і (або) швидкість скидання забруднення у воду біотою зменшується.

Аналогічно побудуємо таке співвідношення за дії будь-якого іншого шкідливого чинника на біоту екосистеми, наприклад, внесення у воду солі важкого металу $P b$. Тоді швидкість забруднення можна задати таким виразом:

$$
a_{12}=a_{12} m, a_{21}=a_{21} n,
$$

де $m$ i $n$ - коефіцієнти впливу важкого металу на параметри стійкості, тоді:

$$
S_{P b}=\frac{S \cdot m}{n}, \text { або } \frac{S_{P b}}{S}=\frac{m}{n} .
$$

У разі дії одночасно кількох чинників можна отримати вираз для визначення площі забруднення $S_{\text {заг }}$ : 


$$
S_{\text {заг }}=S\left(\frac{m}{d n} \sum_{i=1}^{n} c_{1}\right)=\frac{1}{S} \prod_{i=1}^{n} S_{i}, \text { або } \frac{S_{1+2=\ldots=n} S^{2}}{P_{2} S_{1} \times S_{2} \ldots \ldots . \ldots \times S_{i}} .
$$

Загалом за дії $n$-полютантів формула для визначення площі забруднення, через оцінювання синергізму та враховуючи параметри стійкості, буде такою:

$$
S_{n}=\frac{S_{\sum} S^{n-1}}{\prod S_{i}} .
$$

Застосовуючи ці формули для оцінювання синергізму (взаємодії) поліелементного складу батарейок, за результатами експерименту, можна визначити, що значення $S_{n}$ - площі забруднення становить $16,75^{ \pm 0,027} \mathrm{M}^{2}$. Тоді розрахунок екологічного нормативу для кількох чинників повинен задовольняти таке співвідношення: $\sum_{i=1}^{n} \frac{C_{i}}{L_{i}} \leq 0$, де $C_{1}, C_{2}, \ldots, C_{n}$ - реальні значення концентрації поліелементного складу батарейки, а $L_{1}, L_{2}, \ldots, L_{n}-$ встановлені екологічні ліміти.

Для визначення реального екологічного впливу від поліелементного складу батарейки та базуючись на гіпотезі, що склад батарейок можна представити як сукупність елементарних елементів (див. табл. 1), виділимо деяку ділянку одиничної площі. Проведемо верхню межу паралельно до поверхні грунту на висоті $H$, що приблизно дорівнює потроєній висоті дерев $h$. На деякій глибині $R$ за межами шару розміщення кореневої системи проведемо нижню грань. Утворений таким способом паралелепіпед і будемо розглядати як об'єкт забруднення (рис. 4).

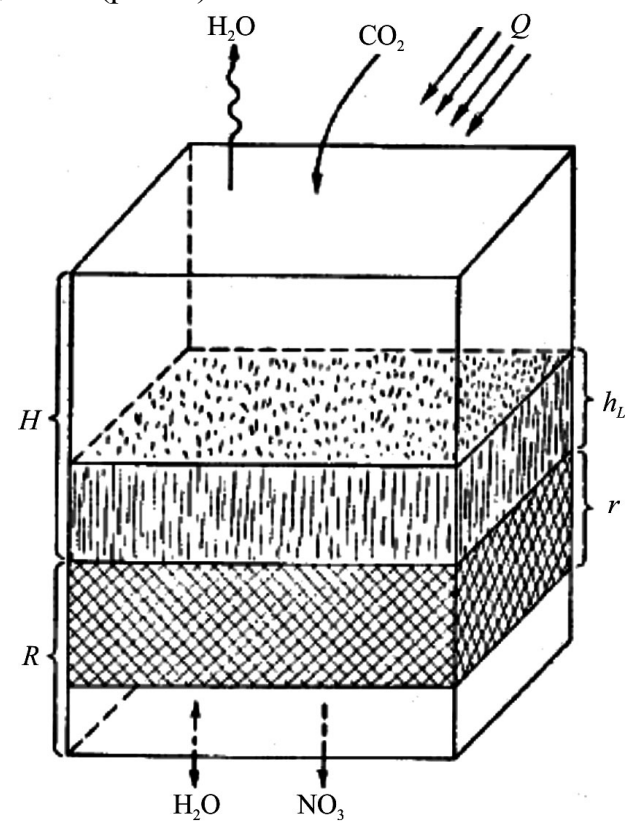

Рис. 4. Об'єкт забруднення поліелементним складом батарейок

Оскільки через бокові грані обмін енергією і речовиною не відбувається, то у виділений об'єм проникає зверху сонячна радіація і вуглекислий газ, а через верхню грань видаляються, наприклад, пари води. Аналогічно означені обмінні процеси відбуваються через нижню грань. При цьому все, що надходить у систему, належить до іiі вхідних впливів, а все що 3 неї видаляється - або до втрат, або до відчужуваного кінцевого продукту. Позначимо спрямовану вгору вертикальну координату через $x$, помістивши ії початок (точку 0) на поверхні грунту. Час позначимо через $t$. У такому випадку всі змінні моделі будуть залежати від двох аргу- ментів $x$ і $t$. У кожен момент часу у системі існує вертикальний розподіл характеристик рослинного покриву, а також різних субстанцій - води у грунті, іонів амонію і нітратів у грунтовому профілі, температури грунту, забруднення полютантами та седиментами і т.ін. У надземній частині системи також існує вертикальний розподіл різних параметрів - антропогенного забруднення, радіації, температури і вологості повітря, температури листя, концентрації вуглецю і азоту у фітоелементах і т.ін.

Знаючи хімізм процесу забруднення грунту та значення самого забруднення, розраховуємо об'єм забрудненого грунту.

Об'єм забрудненого грунту виведемо із загального об'єму забруднення, яке здатна вчинити одна батарейка на одиничній площі:

$$
V_{\text {заг }}=S_{n} A,
$$

де $S_{n}$ - площа забруднення за дії $n$-полютантів, через оцінювання синергізму та враховуючи параметри стійкості (розраховується за формулами 11 та 12) і для у нашому випадку становить 16,$75 ; A$ - межа забруднення одиничної площі полі елементним складом батарейки, розраховується за такою формулою:

$$
A=H+r+K,
$$

де: $H$ - потроєна висота дерева: $h \times 3(h-$ приймаємо рівним середньому значенню висоти дерева - 15 м.); $r$ глибина кореневої системи; $K$ - деяке значення за межами кореневої системи (згідно з експериментальними дослідженнями приймаємо рівним - 3 , виходячи із значення показника забруднення грунту, яке розраховується за формулою

$$
Z_{c}=\sum_{1}^{n} K_{c}-(n-1)
$$

де: $K_{c}=\frac{K_{\mathrm{j}}}{\Gamma Д К}, K_{c}-$ коефіцієнт концентрації хімічної речовини; $K_{j}$ - його фактичний вміст у батарейці; $n$ - кількість підсумкових елементів, вміст яких у грунті перевищує ГДК.

Ступінь небезпеки забруднення грунту оцінювали за чотирьохступеневою шкалою: 1) допустима $-<16$ одиниць, 2) помірно небезпечна - 16-32 одиниці, 3) небезпечна - 32-128 одиниць, 4) надзвичайно небезпечна $>128$ одиниць. Значення показника забруднення грунту поліелементним складом батарейок змінювалися в межах $34,14^{ \pm 1,12}$ одиниць (валовий вміст) і $117,57^{ \pm 1,84}$ одиниці (рухомі форми), $V_{\text {заг }}=16,75 \times 53=887,75, \mathrm{M}^{3}$.

Для грунту це значення становить: $V_{\text {заг }}=16,75 \times 8=$ $134\left(\mathrm{M}^{3}\right)$. Таким способом встановили фактичне значення об'єму забруднення довкілля та площі забруднення грунту, виходячи із теорії надійності екосистеми.

Висновки. Запропонований новий підхід до оцінки впливу не просто батарейки, як такої, а іiі полікомпонентного складу на стан довкілля, через визначення надійності екосистем, дає змогу отримати кількісні показники стійкості та втрати природних екосистем, що можуть бути використані як індикатори стану довкілля, а відтак оцінки екологічної складової, важливої для визначення реального впливу поліелементного складу батарейок. На основі таких показників, які можна отримати за допомогою програмного забезпечення SimaPro, можливий розрахунок тих порогових величин, поза якими відбуваються негативні явища, прогнозування та моделювання ситуацій, картування джерел ризиків, мо- 
ніторинг змін, а це дасть змогу виявити причини цих змін або встановити чинники, що сповільнюють чи стримують наближення екосистем до критичного стану, тобто розробити превентивні заходи запобігання катастрофам.

\section{Перелік використаних джерел}

Didukh, Ja. P. (2011). Ponjattja pro stijkistj ekosystem. Osnovy bioindykaciji, (pp. 288-297). Kyiv: Scientific thought. [In Ukrainian].

Ghrodzynsjkyj, M. D. (1995). Stijkistj gheosystem do antropoghennykh navantazhenj. Kyiv: Likej, 233 p. [In Ukrainian].

Glensdorf, P., \& Prigozhin, I. (1973). Termodinamicheskaja teorija struktury, ustojchivosti ifluktuacij. Moscow: Mir, 280 p. [In Russian].

Gorshkov, V. G. (1995). Fizicheskie i biologicheskie osnovy ustojchivosti zhizni. Moscow: VINITI, 470 p. [In Russian].

Grime, J. P. (1979). Plant strategies and vegetation processes. Chichester: Whiley and Sons, $222 \mathrm{p}$.

Hopper, S. D. (2009). OSBIL theory: towards an integrated understanding of the evolution, ecology and conservationof biodiversity on old, climatically buffered, infertile landscapes. Plant Soil, 322, 49-86. https://doi.org/10.1007/s11104-009-0068-0

Hsing Po Kang, D. (2012). Potential environmental and human health impacts of rechargeable Lithium-ion and Lithium Polymer batteries in discarded cellular phones: evaluation of hazardous waste classification, resource depletion potential, human toxicity potential, and ecotoxicity potential: Tesis of doctor's degree dissertation. Irvine, $115 \mathrm{p}$.

Khan, M. H., \& Kurny, A. S. W. (2012). Characterization of spent household zinc-carbon dry cell batteries in the process of recovery of value metals. Journal of Minerals \& Materials Characterization \& Engineering, 11(6), 641-651. https://doi.org/10.4236/jmmce.2012.116047

Korovin, N. V., \& Skundin, A. M. (Eds). (2003). Khimicheskie istochniki toka. Moscow: Publishing MJeI, 740 p. [In Russian].

Molchanov, A. M. (1976). Ob ustojchivosti jekosistem. Vsestoronnij analiz okruzhajushhej prirodnoj sredy, 212-229. Leningrad: Gidrometeoizdat. [In Russian].

Obshta, A., Bubela, T., Ruda, M., \& Kochan, R. (2018). The Model of Environmental Assessment of Complex Landscape Systems. 18th International multidisciplinary scientific geoconference SGEM 2018 Conference proceedings Volume 18. Water Resources. Forest, Marine and ocean ecosystems ISSUE 3.2. Soils, Forest, Ecosystems, Marine and Ocean ecosystems, July 2-8, (pp. 973979). Albena. Bulgaria - Published by "STEF92 Technology LTD, 51 "Alexander Malinov" Blvd., 1712 Sofia Bulgaria.

Polygalov, S. V., Ilinykh, G. V., \& Bazyleva, Ja. V. (2015). Algoritm sravnitel'noj otsenki vozdejstviya otrabotannykh khimicheskikh is tochnikov toka na okruzhajushchuyu sredu. Modernizatsiya $i$ nauchnye issledovaniya $v$ transportnom komplekse: Materials of the international scientific and practical conference (pp. 270-274). Perm: Publishing Perm National Research Polytechnic University. [In Russian].

Ruda, M. V., Hyvlyud, A. M., \& Lentyakov, V. V. (2018). Application of compartment analysis for modeling of environmental influence of consortium ecotones of protected type. Scientific Bulletin of UNFU, 28(6), 60-68. https://doi.org/10.15421/40280612

Sayilgan, E., et al. (2009). A review of technologies for the recovery of metals from spent alkaline and zinc: carbon batteries. Hydrometallurgy, 97, 158-166.

Svirizhev, Ju. M., \& Logofet, D. O. (1978). Ustojchivost biologicheskih soobshhestv. Moscow: Main edition of physical and mathematical literature, 352 p. [In Russian].

Taganova, A. A., \& Bubnov, Ju. I. (2002). Germeticheskie khimicheskie istochniki toka: Elementy i akkumulyatory. Sposoby i ustrojstva zaryada. (2nd ed.). St. Petersburg: Khimizdat, 176 p. [In Russian].

Zaika, V. E. (2007). Ustojchivost jekosistem. Marine Ecological Journal, 6(3), 27-32. [In Russian].

Zapolskyi, A. K., Saliuk, A. I., \& Sytnyk, K. M. (Ed.). (2001). Osnovy ekolohii. Kyiv: Higher school, 358 p. [In Ukrainian].

I. M. Petrushka, M. V. Ruda, A. M. Hyvlyud, N. M. Kovalj Lviv Polytechnic National University, Lviv, Ukraine

\section{IMPACT OF MULTI-ELEMENT COMPOSITION OF BATTERY ON THE STATE OF THE ENVIRONMENT AND DETERMINATION OF ECOSYSTEM RELIABILITY}

The study was conducted on "EXPERT 3L" model, a device for precision measurements in conditions of stationary and mobile laboratories. To make a quality analysis, it is sufficient by means of the X-ray spectrometer to determine the energy of the XPI-lines from the object and, according to their value, to identify the existing elements. By adjusting the indexes of the hazard level, taking into account the percentage (wt. \%) of each element of the study batteries, you can estimate the consolidated figure of the danger level of the elemental composition of the batteries. When the used batteries get into the stream of solid household waste and when they are subsequently disposed of, due to mechanical damage and corrosion, their hermetically sealed casing is broken resulting in release of toxic substance. High concentrations of lead, cadmium and other heavy metals and compounds that have dangerous properties in batteries subsequently leads to environmental pollution and loss of ecological reliability of the ecosystem. The reliability of the ecosystem is defined as the ability of the ecosystem and its individual parts to withstand the fluctuations of external factors and to maintain its structure and functional characteristics. To assess the impact of not just the battery as such but its multielement composition on the state of the environment, a new approach is proposed through the determination of the reliability of ecosystems, which enables obtaining quantitative indexes of stability and losses of natural ecosystems. In the light of ensuring the transition of society to the principles of sustainable development, it is important to assess the risk of losses, the destruction of ecosystems, which is closely connected with their stability. Ecosystem stability is seen as the ability to maintain its structure and the nature of its functioning in space and time despite changes in the environment. These data can be used as indicators of the state of the environment, and hence as the assessment of an environmental component that is important for determining the actual impact of the multi-element composition of batteries. On the basis of such indicators, which can be obtained using the SimaPro software, it is possible to calculate thresholds beyond which negative phenomena occur, as well as to predict and simulate situations, to perform the mapping of sources of risks, to monitor changes, and this will allow identifying the causes of these changes or determining the factors that slow down or retard the approach of ecosystems to a critical state, i.e. to develop preventive measures to avoid disasters. The eco-indicator 99 is one of the methods that allows accepting one estimate for the whole product - the so-called ecological index. It is the sum of all individual eco-points or partial indexes for all life-cycle processes. The computational procedure is carried out by summing up the results of weighing the phases of the life cycle.

Keywords: reliability; ecosystem; batteries; multi-element composition; SimaPro; impact. 